\title{
《舞妓林泉》に見る土田麦僊の庭園観
}

\section{Tsuchida Bakusen's View of Gardens Observed with "Bugi-Rinsen"}

\author{
小 野 健 吉 \\ Kenkichi ONO \\ 奈良国立文化財研究所
}

\begin{abstract}
Key Words: 1. 《舞妓林泉》
2. 人工美

3. 天授庵庭園

"Bugi-Rinsen"

Artificial Beauty

Tenju-an Garden
\end{abstract}

\section{要旨}

大正時代から昭和初期にかけて活躍した京都の日本画 家・土田麦僊は数多くの<舞妓図〉を描いたが、なかで も《舞妓林泉》（大正13年・1924）は、舞妓の背景とし て庭園を詳密に描いた点で他の作品とは趣を異にする。 この作品で麦僊が描いた庭園は、京都南禅寺の天授庵庭 園であった。麦僊は、池・出島・石組・岩島・石橋・ 、 ツ・カエデ・借景の山といった諸要素からなる京都の典 型的な池庭を、人工的な女性美の極致である舞妓に最も ふさわしい風景として、自らの美意識に基づいて選んだ のである。彼は、この庭に「自然以上の美」を感じてい たに違いない。

\section{Summary}

Tsuchida Bakusen (1887-1936) is an artist who played an important role in the field of Japanese painting from Taisho period to early Showa period. He painted a lot of pictures of 'Maiko'. "Bugi-Rinsen (A Maiko and a Garden)" is one of his most important 'Maiko' pictures. But it is different from other 'Maiko' pictures, because a garden was fully painted as a background. The garden is that of Tenju-an Temple at Nanzen-ji in Kyoto. It is consisted of a pond, a peninsula, arranged stones, stone islands, a stone bridge, pine trees, maple trees and a background mountain. It is a traditional pond garden in Kyoto. Bakusen thought that this kind of garden was a most suitable landscape for 'Maiko', the ideal of artificial beauty in a sense. This choice reflects his view of gardens.

\section{1.はじめに}

明治時代の後半から昭和時代の初期にかけての京都に おける庭園を考えるうえで、画家のはたした役割に注目 する必要があることは筆者がすでに指摘してきたところ である1。神坂雪佳は依頼されて庭園のデザインにかかわ ったことがあるし、竹内栖鳳や橋本関雪は自邸の庭を自 らの手でデザインした。また中原哲泉は、『植治』こと小 川治兵衛のために庭園の完成予想図または設計図といっ たものを描いた。そして、作品（絵画）のなかで古庭園 を題材とした例としては、明治43年（1910）の第10回文展 に洋画家・鹿子木孟郎が出品した《林泉》や大正13年 （1924）の第 4 回国展に土田麦僊が出品した《舞妓林泉》 が知られる。このうち《林泉》は京都天龍寺曹源池を真 正面からとらえて写実的に表現したものであり、《舞妓 林泉》は南禅寺天授庵の庭と舞妓を綿密な写生に基づき つつ構成的に描いた作品である。前者については「名所 絵的」との指摘2もあるが、現在、作品の所在が不明なこ ともあって論考は多くはない。一方、後者は麦僊の代表 作の一つといえるもので多くの論考があるが、それらは おおむね麦僊が数多く描いた〈舞妓図〉の文脈上のもの であり、く林泉〉に着目したものは数少ない3)。

本稿では、この《舞妓林泉》の少くとも主題の半分で あるく林泉〉に着目して麦僊の庭園観を探ってみたい。 実際の庭園デザインにかかわったわけではないにしても、 
「まちがいなく近代を代表する傑出した日本画家、その伝 統を新しく生気づけた一人の優秀な芸術家」4)と評価され る麦偠の庭園観に考察を加えることはこの時代の庭園意 匠にも影響を及ほした美意識の一面に光をあてることで あり、近代日本庭園史の研究にとっても意味のないこと ではないと考える。

\section{2. 土田麦偠}

麦僊の芸術観に立ち入る前に、まず、作品を中心として その生涯を概観しておきたいす。

麦僊は、明治20年 (1887)、新潟県佐渡の農家の三男と して生まれた。4才年下の弟である茂は、長じて哲学 者・土田杏村となる。麦僊は、「自分は神童といはれる 迄一田舎によくある一画好きの児であった」のと回想する ほど絵画の才能に恵まれていたが、小学校卒業後は正覚 坊という寺に預けられた。明治36年（1903）、その正覚坊 の住職に連れられて京都の智積院に入ったことが麦僊の 大きな転機となる。彼は画家を志して智積院を出奔、京 都の日本画家・鈴木松年に入門し、松年の息子である松 僊の教えを請うことになる。翌明治37年（1904）病気で 一旦帰郷後再び京都に戻り、竹内栖鳳に入門、ここで 「麦僊」の号をうける。入門時の麦偠は、その制作を見た 同門の先輩・橋本関雪が「『あいつは一寸こはい奴だぜ』 と傍らの者にささやいたことがあった」わという逸話が残 っているほど、注目されたのである。入門から 3 年後の 明治40年（1907）の第12回新古美術展に出品した《春の 歌》が二等賞一席（首席）を受け、その翌年の第二回文 展では《罰》で三等賞を受賞する。また、明治43年 （1910）に京都市立絵画専門学校を卒業するが、このとき の卒業制作《髪》が学校買上げとなる。こうした創作活 動の一方、明治42年（1909）に、美学者・中井宗太郎な どを中心にした研究会「無名会」に出席して西洋近代美 術理論に接したのを契機に、「黒猫会（シャ・ノワール）」 や「仮面会（ル・マスク）」などの懇談会の中心メンバー となり、美学者、評論家、洋画家などとの交流のなかで 美術理論に対する知識を深めていく。

大正元年（1911）、八丈島に取材した《島の女》を第 6 回文展に出品して入選。それまでの写生に重点をおいた 作風から一変して自由な表現を試みたこの作品は話題を 集めた。翌大正 2 年（1912）には、さらにこの傾向を押
しすすめた《海女》を第 7 回文展に出品。三重県志摩波 切に取材したこの作品には、明らかに後期印象派の画家 ゴーギャンの影響が見られ、その表現に対しては賛否两 論の議論を引き起こしたが、文展では落選となった。こ の後、大正 3 年（1914）には古画の研究成果ともいえる 《散華》、大正 4 年（1915）にはルノアールの影響が見 られる《大原女》、大正 5 年（1916）には自らの美的人 メージの具象化たる 《三人の舞妓》、大正 6 年（1917） には中国古画の研究成果をとりいれた《春禽趁晴図》と、 自らの表現法を模索するかのように、さまざまな表現様 式に挑戦している。こうした創作活動を経て大正 7 年 （1918）には、村上華岳、榊原紫峰、小野竹喬、野長瀬晚 花らとともに国画制作協会を結成し、この年の第 1 回国 画創作協会展（国展）に《湯女》を出品する。大正10年 （1921）自編の『麦僊画集』を出版。大正10年（1921）の 秋から大正12年（1923）の春にかけてヨーロッパに遊学。 フランスを中心に、イタリア・イギリス・スペイン・オ ランダ・ドイッ・ベルギーなどでヨーロッパ絵画にじか にふれるとともに、自らの風景画、人物画の研究にも打 ち込み、その後の平明で格調高い作風への基盤を形成す る。帰国後、大正13年（1924）の第 4 回国展に《舞妓林 泉》、昭和 2 年（1927）の第 6 回国展には 3 年がかりの 大作《大原女》を出品するなど国画創作協会の中心とし て活躍する。国画創作協会第一部（日本画）が経済的な ゆきづまりから、昭和 3 年（1928）に解散してからは、 帝展と七絃会を中心に出品を続けることになる。《罌 栗》（昭和 4 年・1929）、《明粧》（昭和 5 年・1930）、 《平牀》（昭和 8 年・1933）などは帝展に、《麗日》 （昭和 4 年・1929） 《山茶花》（昭和 8 年・1933）などは 七絃会に出品された作品である。このうち《平体》は、 未完の遺作となった《妓生の家》とともに朝鮮で取材し た作品であり、平明で格調高い晚年の代表作である。昭 和11年（1936）、49歳で逝去。

\section{3．麦僊の芸術観}

麦偠は芸術に対して、きわめて真摰な態度を持ち続け た芸術家であった。そして、そのことは画家としては多 く残した書簡や随想などの文章からも読みとることがで きる。こうした彼の文章については、すでにいくつかの すぐれた研究があるが8、ここでは、彼の芸術に対する考 
え方あるいは姿勢といったことを考えるうえで最も重要 な資料といえる『日本画に就ての雑感』『人の舞妓に就 ての雑感』『雑感』(いずれも『麦僊画集』大正 10 年 1921所収) から、主だった部分を引用し、その芸術観の 片鱗にふれてみよう。

「自分は対象其物を如実に画くといふ事が芸術の基調をな すものだと考へて居る。敬虔な心を以て自然に㻊帱する 事から本当の芸術は生れるものだと考へて居る。自分は 自然を追窮する事に一生を費しても悔いないと思子。」 「個性といふものは生れながらにして神から人間に恵まれ たものである。然し自分は個性の鋳型を作りたくないと 思って居る。（中略）自力よりも他力だ。自然の前に謙譲 であり、人生の前に敬虔なる時自分の個性は内に䰢る。 それが本当の個性だと思ふ。」「自然を写すといふことは 已に自分の心の空を透した自然である。だから厳密なる 写実画はあり得ない。空想を画くといふ事も其人に取っ ては確かな実感である。だから厳密なる空想画もあり得 ない。(以上『日本画についての雑感』)、「自分は舞妓を 描くからといって決して享楽的な態度から描いては居な い。自然は無限に美しいけれども自分の心は尚自然以上 の美に憧がれて居る。それがキラキラと輝くものであっ たり、又焔の様に燃へ上る感じであったりする。この内 に憧れて居る美の感じは、只舞妓といふ対象を借りたに 過ざない。舞妓がこの自分の心に輝く美の憧れを托する に最も都合よき対象であった為に。」(『三人の舞妓に就て の雑感】、「写実といふ事はまづ美術の第一歩だ。しかし 自分は如何なる自然、如何なる対象を写しても悉くそれ が立派な画になるとは考へない。自分等が画になるモチ 一フを捜し求めるといふ事は既に自分の内なる美の憧が れが自然以上のものを求めて居るからではないか。「自 分は写実の美と装飾の美との渾然融和したものが描きた い。自分の心の内なる美の憧がれは自然の浄化を思ふ。 想像の美が生れ、装飾の美が生れる所以である。しかし 装飾の美は自然の浄化からのみ生れない。対象を自然に 借らず、只其すぐれた芸術家の心のリズムから生れた訳 の分らない線、或は色、殆ど空想から描かれたものにも、 我々は装飾の美を感ずる事が出来る。(以上『雑感』)。

それぞれの文章で、その主張には若干の振幅が見受け られる。しかし、その真意を推測してみると以下のよう に要約できるのではないか。「写実は基本であるが、それ
だけで芸術としての十分条件とはなりえない。自らの持 つ内なる美意識を表現してこそ芸術となりうるのであり、 その内なる美意識は自然や人生に対して敬虔であること によって質を高められるものである」と。生涯をつうじ て、麦偠は、こうした考えを保持し続けたといってよい だろう。そして、麦偠にとって自らの美意識を托する最 も適切な対象の一つが舞妓であったわけである。

\section{4. 《舞妓林泉》}

舞妓は、「延宝・天和年間（1673～84）、八坂神社の社 頭の茶屋の茶汲み女が歌舞伎芝居の芸をまね、八坂神社 参拝の旦那衆に見せたのが起こり」9といわれ、さらにそ の後、京都の社交の伝統のなかではぐくまれてきた一つ の究極の女性の装いのかたち、換言すれば、人工的な女 性美の一つの極致である。

麦僊は、大正 5 年（1916）の《三人の舞妓》以後、 《舞妓林泉》《明粧》《燕子花》（昭和 9 年・1934）な ど舞妓を主題とした作品を数多く描いている。自ら「自 分の心に輝く美の憧れを托するに最もよき対象」(『三人 の舞妓についての雑感』）というように、舞妓は彼にとっ て終生最も重要な主題であった。ところで、ここでこれ ら一連の<舞妓図>の前景あるいは背景に注目してみよ う。《三人の舞妓》では、前景として舞妓の興じるトラ ンプと舞妓の一人の持ち物である扇子が描かれているた けである。《明粧》では、色彩的にも形態的にもシンプ ルな柱・疊・襖の直線で構成される和室内に正座する舞 妓の前に漆塗の盆が置かれているだけで、濡れ縁・策の 向こう側の屋外にもムべの蔓がわずかに見られるに過ぎ ない。また、平安神宮神苑に取材したともいわれる10 《燕子花》も二人の舞妓の左手前に燕子花を添景的に描 いているだけで、背景は描かれていない。このように、 麦僊の<舞妓図〉において、舞妓の前景あるいは背景は、 主題である舞妓の美を引き立てるよう厳しく吟味されて いることがうかがえる。その結果、前景あるいは背景は 相対的に希薄になり、主題としての舞妓が浮き出るよう にきわだって表現されることになる。こうしたなか、 《舞妓林泉》では、背景として庭園が詳密に描かれてい るのが特に目を引く。この絵の描かれたのが一年半に及 ぶヨーロッパ遊学からの帰国後間もない時期であり、前 面に人物、後方に遠景を置くイタリア・ルネッサンス期 


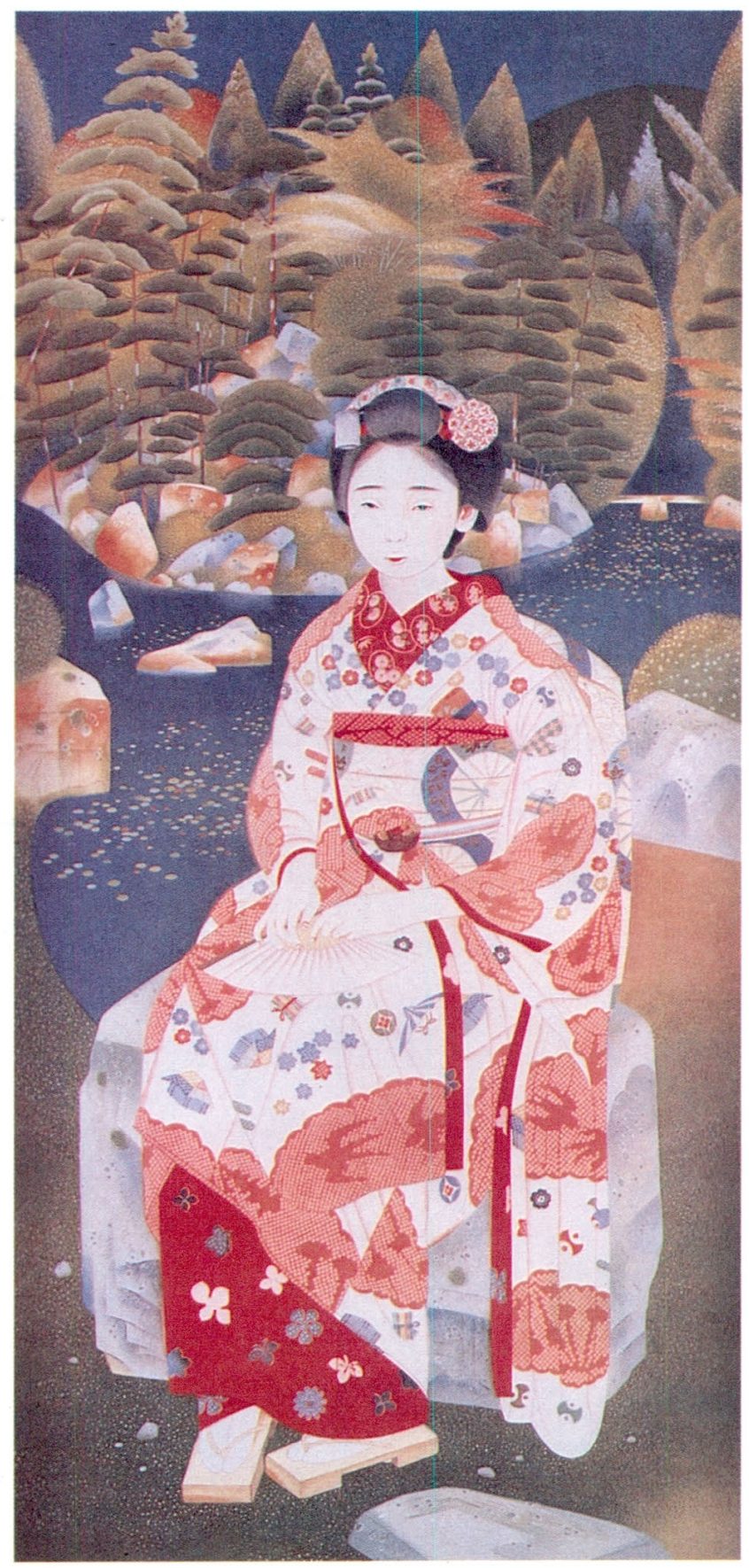

図 1 《舞妓林泉》（東京国立近代美術館蔵）

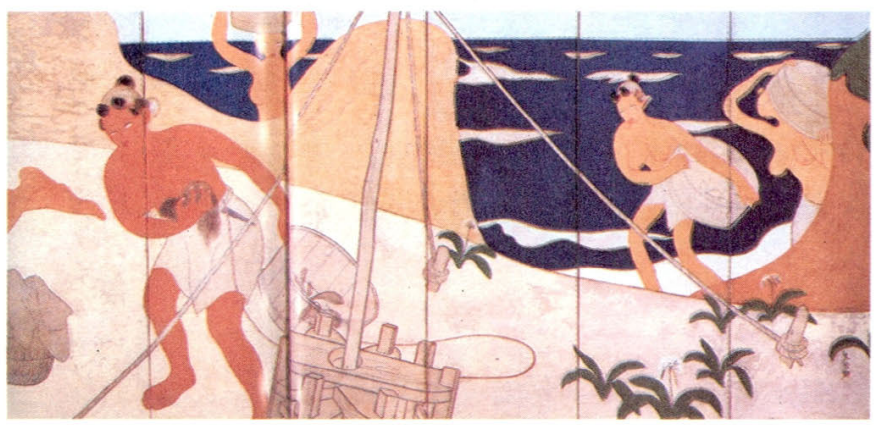

図2《海女》〔左隻〕(京都国立近代美術館蔵)

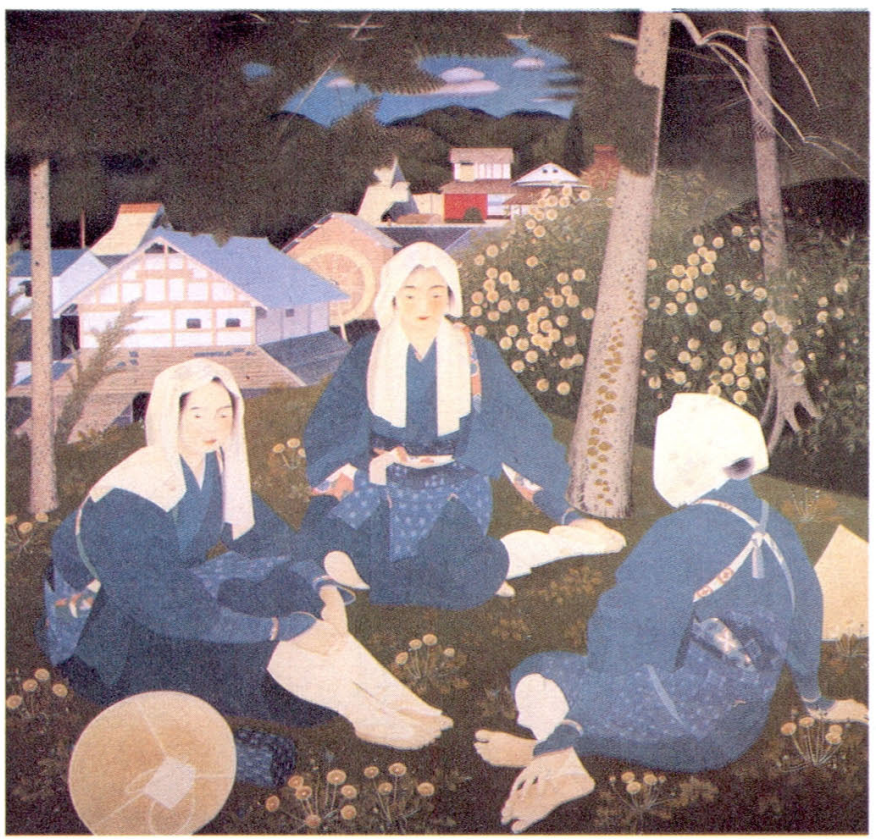

図3《大原女》(京都国立近代美術館蔵)

表13作品における人物と風景の人工度

\begin{tabular}{|c|c|c|c|}
\hline & 人物 & 風景 & 作品名 \\
\hline \multirow{2}{*}{ 人 小 } & 海女 (半裸婦) & 海浜 & 《海女》 \\
\hline & 大原女 & 山里 & 《大原女》 \\
\hline 度 大 & 舞妓 & 庭園 & 《舞妓林泉》 \\
\hline
\end{tabular}

の絵画の構図からの影響も指摘される吕ところであるが、 そうであるにしても、きわめて大切にしていた主題であ る舞妓の背景として、しかも舞妓と同等に詳密に描くに 足る風景すなわち自らの美意識を托するに足る風景とし て、吟味を重ねて選んだのがこの庭園であったことに変 わりはない。さらに、画題として「舞妓」と「林泉」を 並立させていることは、麦偠がこの庭園を人工的女性美 の極致ともいうべき舞妓に最もふさわしい人工的風景美 の極致と認識していたことを物語っているといえるだろ $j^{12)} \circ$

次に《舞妓林泉》（図 1) に描かれた内容に注目して みよう。縦長の画面 $(218 \mathrm{~cm} \times 102.3 \mathrm{~cm})$ の中央から下部 にかけて大石に腰掛ける盛装の舞妓を置き、その背景に 池庭が広がる。池には奥から出島が張り出し、岩島が浮 かぶ。出島には石組が組まれ、右手から石橋が架かる。 出島のマツやカエデ、その後乃のスギなどの植栽の背後 には円味を帯びたおだやかな姿の山が借景として描かれ ている。そして、麦僊が人工的風景美の極致と認識して 


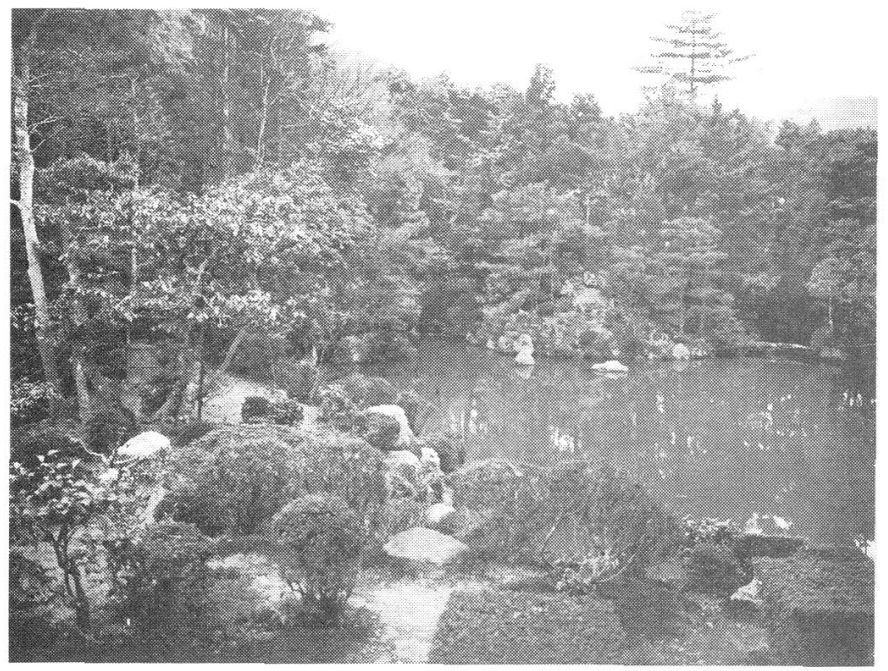

写真1「南禅寺天授庵庭園・書院より莲莱山附近 を見たる全景」(重森三玲「日本庭園史図鑑・明治大正昭 和時代一」1937所載)

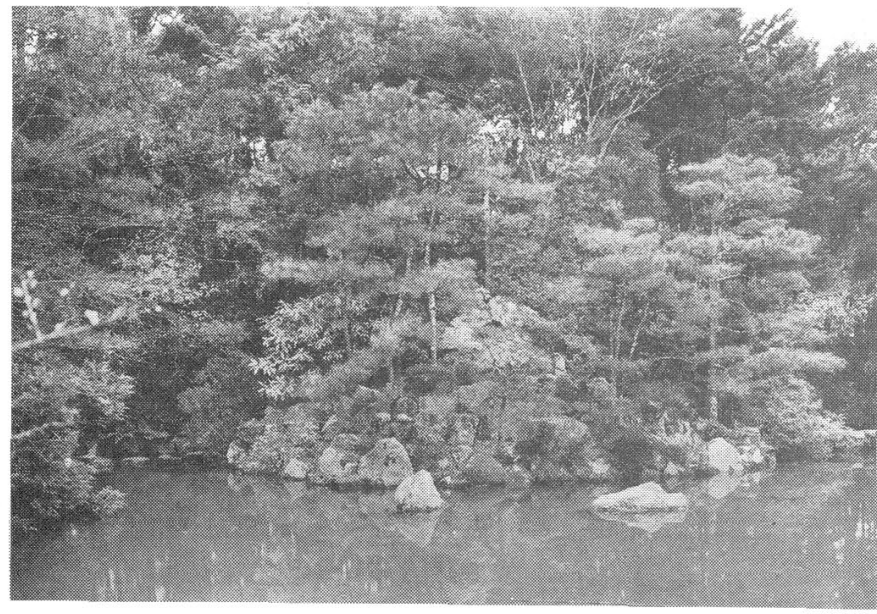

写真2「天授魔庭園・下部池泉蓬莱出島・石組手 法」(重森三玲「日本庭園史図鑑・明治大正昭和時代一」 1937所載)

いたと考えられるこの庭園と人工的な女性美の極致であ る舞妓との取り合わせは、麦偠のねらいどおり見事に成 功した。

じつは、人物と風景との取り合わせについては、麦傮 はこれ以外の作品においても、綿密な計算にもとづいて 創作を行っている。その代表的な例は、《海女》（図 2) と《大原女》（昭和 2 年・1927／図 3 ）であろう。《海 女》は、その大胆な表現手法に注意が向けられがちであ るが、半裸の海女という自然のままに近い姿の人間と、 素朴な漁具や舟を置いている以外は自然のままの海浜風 景という取り合わせもまた麦僊の十分な計算の所産であ ることを見逃してはなるまい。《大原女》は《舞妓林 泉》と同じくヨーロッパ遊学後の作品である。大原女と

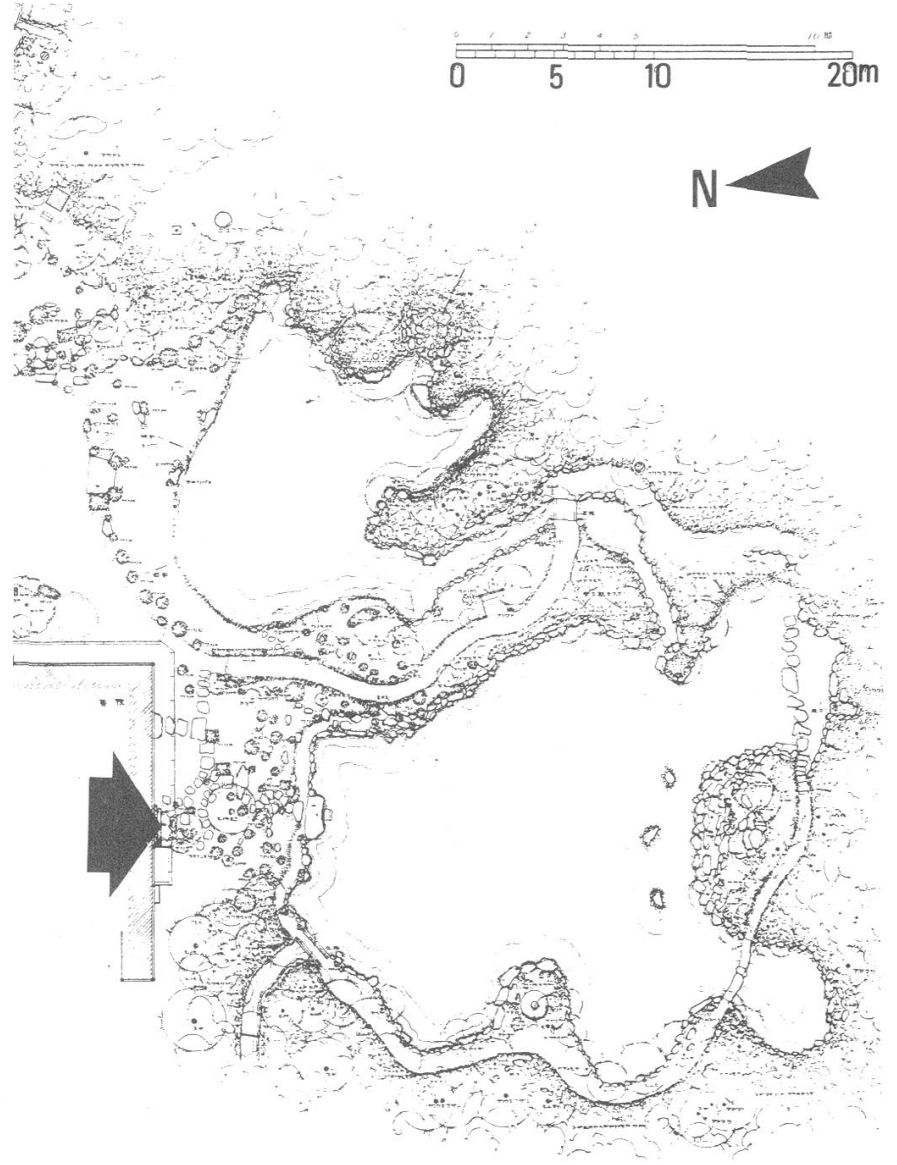

図4天授庵庭園実測図〔部分〕(重森三玲「日本庭園 史図鑑・明治大正昭和時代一」1937所載) 矢印は《舞妓林泉》における庭園の写生方向を示す。

は、「頭に縫紋様のある手拭をかぶり、紺衣に御所染の帯 を締め、二巾半の前だれを腰につけ、手には白の甲掛と 脚絆、草鞋に白足袋といういでたちで、頭上に薪・柴な

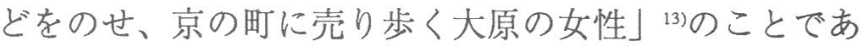
るが、この作品では、おちついた里の風景を背景に、野 に腰を下ろす 3 人の大原女が描かれている。その人物と 風景は、《舞妓林泉》のそれらほど人工的ではなく、さ りとて《海女》のそれらほど生に近い自然の姿でもない。 いわば、その中間に位置する人物と風景であり、その取 り合わせもまた、麦偠が計算し尽くしたものであるとい ってよいだろう。《海女》《大原女》《舞妓林泉》の 3 つの作品における、人物と風景の人工度をまとめてみる と、表1のようになる。

\section{5. 天授庵庭園}

《舞妓林泉》に描かれた庭園、すなわち麦僊が盛装の 
舞妓に最もふさわしいものとして選んだ庭園は、京都の 南禅寺の塔頭のひとつ、天授庵の庭園であった ${ }^{14)} 。$ 重森 三玲によれば、この庭園の原形は慶長 7 年（1602）細川 幽斎が方丈その他を寄進建立した際に築造されたが、そ の後荒廃していたものを明治37～38年（1904～1905）頃、 住職の虎山恭宗が改修したものであるという15)。したが って、麦僊が描いたのはこの明治の改修からおよそ20年 を経た姿であった。天授庵の庭園は、書院の南方の上下 2 段の池が中心となる。《舞妓林泉》の背景として描か れているのは、このうち下段すなわち西側の池である。 《舞妓林泉》（図 1 ）と『日本庭園史図鑑』に掲載され ている昭和10年（1935）頃の写真（写真 $1 \cdot 2 ）$ を比べ てみよう。舞妓が腰掛ける大石は庭に実在しないもので あるが、その他の景物、すなわち、池に浮かぶ岩島、出 島の石組と植栽、出島右手の湾に架かる石橋などの配置 を麦偠はかなり忠実に表現していることがわかる。麦僊 は、書院付近から南を向いて絵筆をとったのである（図 4 )。

ところで、麦偠は、京都の数ある古庭園のなかからど うして天授庵の庭園を選んだのであろうか。天授庵の庭 園は、例えば鹿子木が《林泉》で描いた天龍寺の庭園の ような当時すでに高い評価を受けていた庭園 ${ }^{16) て ゙ は な い 。 ~}$ したがって、舞妓に最もふさわしい庭園として、かっ自 らの美意識に基づく庭園観によって、この庭を選んだこ

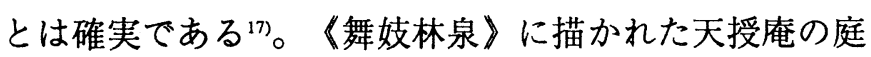
園の西池の部分は、池と池に浮かぶ岩島、池にせり出し た出島と出島上の石組やアカマツ・カエデ・サツキとい った植栽、石橋、庭の背後のスギ木立ち、借景としての 山というふうに、京都の近世以後の池庭の主要な要素が ほほ網羅されている。しかも、それらを舞妓を前景に置 いた縦長の画面に見事に収めている。もとより、絵画で あってみれば、イメージする庭園の要素を複数の庭園か ら採って画面の上で再構築することも可能である。しか し、麦偠はそれを行わずに、自らの美意識に基づく庭園 観に合致し、描こうとする舞妓の絵の構想に適合する庭 園をさがしだした。重森三玲は、虎山恭宗による天授庵 庭園西池部分の改修をかなり痛烈に批判しているが18)、 麦偠にとっては、そうした改修の有無もしくは是否など 眼中になかったのである。

\section{6.麦偠の庭園観}

最後にこれまで述べてきたことを中心に、麦僊の庭園 観に考察を加えて、まとめとしたい。

麦僊のく舞妓図〉のなかで《舞技林泉》ほど背景・前 景を詳密に描いた作品はないこと及び《海女》《大原 女》との比較からうかがえるように、京都が生みだした 人工的な女性美の一つの極致である舞妓にふさわしい風 景として麦僊は庭園をえらんだ。その庭園は、枯山水で も露地（茶庭）でも、あるいは洋風の要素を持つ庭園で もなく、前述したように池・出島・石組・岩島・石橋・ マツ・カエデ・借景の山といった様々な構成要素からな る、近世以降の京都の典型的な池庭の外観をそなえたも のであった。こうしたタイプの庭こそ、麦僊にとって舞 妓一「自然は無限に美しいけれども自分の心は尚自然以 上の美に憧がれて居」り、「それがキラキラと輝くもので あったり、又焔の様に燃え上る感じであったりする」 (『人の舞妓に就いての雑感』）自らの美意識を托するに 最もふさわしい対象であった舞妓一と取り合わせるに值 するものだったのである。さらに言えば、このタイプの 庭園にもまた、舞妓と同様に「自然以上の美」(『三人の 舞妓に就いての雑感』）を感じていたとも言えようか。

麦僊の長女・辻鏡子によれば、京都等持院にあった麦 僊の自邸の庭は、「庭に石を置くことは子供のあそびに危 険と、いつも雑草の生えるにまかせてあったが、時には 盧美人草が風に摇れたりしていた」19 という。師であっ た竹内栖鳳やかって同門であった橋本関雪のように自邸 に粋をこらした庭園をしつらえることはなかった。しか し、「端然として静かに、一種の近代的知性をさえ感じさ せる格調を生み出す表現はかつてなかった。」200と評され る《舞妓林泉》の画面に、麦僊は自らの庭園観を確実に 定着したわけである。

\section{註}

1）小野健吉「神坂雪佳の作庭とその意義について」、「造園雑 誌」 49 巻 5 号、P.49 54、1985、同「竹内栖鳳と霞中庵」、昭 和63年度日本造園学会関西支部大会研究発表要旨小、P.27 28、 1988、同「神坂雪佳と中原哲泉」、植治の庭一小川治兵衛の世 界小P.220 224、淡交社1991。

2) 山梨絵美子「庭にモチーフを得た黒田清輝の作品とその自 然観」、明治美術学会第49回研究報告」、P.25、1990。 
3 )「日本画表現の革新一《舞妓林泉図》」(「日本の近代美術 5 ·京都の日本画」大月書店・1993.10所収）において、廣田孝 が庭園の描写等についてかなり詳しく述べている。

4 ）河北倫明「青年麦僊の画論」、「巨匠の名画 15 土田麦偠」 P.84、学習研究社、1977。

5 ) 内山武夫編「土田麦偠年譜」、「土田麦偠展 ·図録」、P.164 ～167、大須賀潔「土田麦僊一人と芸術一」、「土田麦僊展 ·図録」、 P.138～145、（京都市美術館1984）を参考にした。

6 ）土田麦僊「日本画に就ての雑観」、「麦偠画集」、P.1、山本 画嘎堂、1921。

7 ）村松梢風「土田麦僊」、「本朝画人伝巻 5 」、P.316、中央公 論社、1943。

8 ）河北倫明「青年麦偠の画論」、「巨匠の名画15 ·土田麦僊」、 学習研究社、1977。弦田平八郎「連載・土田麦偠の書簡」、「三 彩小、224号、P.54 57、225号、P.40 43、226号、P.60 63、い ずれも1968。田中日佐夫編「土田麦偠の野村一志あて書簡」、美 学美術史論集第四輯、成城大学大学院文学研究科、1984。田中 日佐夫編「土田麦僊のヨーロッパからの書簡」、成城大学、1987。

9 ）「京都大事典」、淡交社、1984。

10）加藤類子は、「アサヒグラフ別冊美術特集 土田麦偠」（朝 日新聞社1990）「作品解説71燕子花（草稿）」なかで、平安神 宮神苑に取材した可能性を指摘している。

11）内山武夫「舞妓林泉」、「日本画素描大観六 土田麦偠」、 P.226、講談社1985、加藤類子「作品解説40舞妓林泉 - 舞妓林泉 草稿」「アサヒグラフ別冊美術特集 土田麦偠」、朝日新聞社、 1990など。

12）舞妓と庭園を組み合わせた、他の画家による作品としては 穼本一洋（1893～1952）の《餞春》（1928）が知られるが、こ の作品の主題の取り方は《舞妓林泉》からの影響が少なからず あるのではなかろうか。

13）竹村俊則「昭和京都名所図絵 3 - 洛北」、P.115 116、京都 書院、1982。

14）〈舞妓林泉〉に描いた庭について、麦偠自身が天授庵の庭 であることを直接語った資料は見当らない。しかし、麦偠から 直接ないしそれに近い聞き取りができる立場にあった加藤一雄 が「日本近代絵画全集22 土田麦僊・村上華岳」(講談社1962) の〈林泉舞妓図〉(ママ)の解説で「背後の林泉は南禅寺塔頭天授 庵の庭である」と書いていること、1967年にこの絵を印刷した 切手が発行されたさい麦僊夫人の土田千代とモデルであった今 井フミらに天授庵の庭で郵政大臣から記念の切手シートが贈ら れたこと（読売新聞・1967年4月22日）などから、そして何より もその描かれた景色から判断して、この庭が天授庵であること は間違いなかろう。

15）重森三玲「日本庭園史図鑑・明治大正昭和時代一」、P.28
32、有光社、1937。

16）天龍寺庭園は、大正12年（1923）、史蹟名勝天然紀念物保存 法により名勝に指定されている。

17）舞妓と組み合わせるに足る庭園を求めて、麦偠が写生した 複数の庭園のスケッチが現存する（内山武夫「舞妓林泉」「日 本画素描大観六 土田麦偠」P.226 ・講談社1985)。なお、天授 庵庭園のこの部分は、後に（1941）宇田荻邨（1896～1981）が 《林泉》として、《舞妓林泉》とほほ同じアングルで描いてい るが、いうまでもなくこれは《舞妓林泉》からの影響を受けて いる。

18）重森三玲は前掲書のなかで「本庭では先づ第一に、南方出 島の蓬莱山石組が目につく訳であるが、この部分は、実際なら ば中島とすべきを、流石に時代が明治である関係から、この出 島を利用して蓬莱石組を行ったのである。然しながらこの石組 手法を見ると、護岸としての一段と、更にその上に二段の集団 石組とされ、や、古手法をとられてはなるが、これを仔細に見 ると、甚だ力弱く、且つ乱雑であって、中央上部の石組の如き 全く素人くさいのみでなく、明治時代に於ける蓬莱石組が如何 に邽落したであらうかを研討する上によき資料となるほど、実 はそれほど甚だ拙ないものがある。集団石組の手法にしても、 これが出島の関係で斯くするより外に名案がなかった程度で、 古手法などは全然表現されてなないのみでなく、甚だ勝手自由 な石組とされてるる。と述べている。

19）辻鏡子「回想の父土田麦偠」、P.105、京都書院、1984。

20）大須賀潔「作品解説35舞妓林泉」、「土田麦偠展図録」P.150、 京都市美術館編、1984。 